\title{
Bio-orthogonal Affinity Purification of Direct Kinase Substrates
}

\author{
Jasmina J. Allen ${ }^{\ddagger}$, Scott E. Lazerwith ${ }^{\dagger}$, and Kevan M. Shokat ${ }^{\star}$ \\ Departments of Cellular and Molecular Pharmacology, University of California, San Francisco, \\ California 94143, and Department of Chemistry, University of California, Berkeley, California 94720
}

\begin{abstract}
Protein kinases mediate signal transduction through phosphorylation of their protein substrates. ${ }^{1} \mathrm{Up}$ to one-third of proteins in a cell are phosphorylated, ${ }^{2}$ and a major goal of phosphoproteomics is to characterize phosphorylation mediated signaling cascades by identifying phosphorylated proteins. This feat is analytically challenging because most phosphoproteins are of low abundance and substoichiometrically phosphorylated. Further, once a phosphoprotein is identified, it is difficult to integrate the role of the phosphorylation event into signal transduction networks without knowledge of the upstream kinase. Affinity purification techniques, such as strong cation exchange (SCX), ${ }^{3}$ immobilized metal ion affinity chromatography (IMAC) ${ }^{4}$ chemical tagging of phosphorylated residues with biotin, ${ }^{5}$ and phosphomotif specific antibodies ${ }^{6}$ can enrich phosphopeptides or proteins, but the information regarding the kinase responsible for phosphate transfer is uncoupled from the phosphorylation event. We previously have described methodology that allows selective labeling of direct kinase substrates, using analogue specific (as) kinases and orthogonal unnatural nucleotides $(\mathrm{A} * \mathrm{TP}$ and $\mathrm{A} * \mathrm{TP} \gamma \mathrm{S}),{ }^{7}$ however, it remains challenging to biochemically isolate the labeled substrates, impeding their identification.
\end{abstract}

Here, we report a technique that combines direct substrate labeling with immunoaffinity purification (Schemes 1 and 2). To label the substrates of a given kinase, an as allele is used to enzymatically label substrates with $\mathrm{A} * \mathrm{TP} \gamma \mathrm{S}$. The selectively introduced thiophosphate is then chemically derivatized to construct a bio-orthogonal affinity tag. This approach is similar to other bio-orthogonal tagging strategies using ketones ${ }^{8}$ or azides, ${ }^{9}$ except thiophosphate cannot be selectively tagged in a single chemical step. For example, an alkylating agent will label both thiophosphate and other cellular nucleophiles, but we envisioned that an antibody could discriminate the thiophosphate alkylation products from other undesired alkylation products. The alkylating agent $p$-nitrobenzylmesylate (PNBM) was selected to construct the epitope because we predicted antibodies could recognize the product of thiophosphate alkylation over other nitrobenzyl alkylated amino acid residues, based on unique size and charge. Also, several high affinity antibodies have been raised against haptens containing $p$ nitrophenyl moieties, ${ }^{10}$ increasing the chances of eliciting an antibody capable of immunoprecipitation. Antibodies raised against hapten $\mathbf{4}$ are likely to be sequence independent because the binding determinants are relatively distant from the peptide backbone.

Utilizing hapten 4, polyclonal antibodies ( $\operatorname{IgY}$ and $\operatorname{IgG}$ ) were raised in chickens and rabbits, respectively. ${ }^{11}$ To enrich for specific binders, immune antibodies were purified on an affinity column containing immobilized hapten 4 . Chicken IgY antibodies $(\alpha-3-\operatorname{IgY})$ performed best

\footnotetext{
shokat@cmp.ucsf.edu.

*Program in Chemistry and Chemical Biology, UC San Francisco.

†Current Address: Pfizer Inc. Ann Arbor, MI 48105.
}

Supporting Information Available: Details for experimental procedures, synthesis of hapten 4, ELISA data, Mob1 Western Blot, immunoprecipitation controls, and a table of ATP $\gamma \mathrm{S}$ utilizing kinases. This material is available free of charge via the Internet at http://pubs.acs.org. 
in immunoprecipitations and were used in subsequent experiments. To investigate $\alpha-3-\operatorname{IgY}$ binding requirements, cyclin dependent kinase $1(\mathrm{Cdk} 1)^{12}$ substrates, Histone H1 (H1) and Swe1, were derivatized and tested in immunoassays.

The $\alpha-3$-IgY antibodies only successfully recognized $\mathrm{H} 1$ that had been thiophosphorylated and PNBM alkylated. In control experiments, untreated H1, PNBM alkylated H1, or thiophosphorylated H1 were not detected by ELISA (Supporting Information Figure S2). Similarly, $\alpha-3-\operatorname{IgY}$ recognition of the substrate $S w e 1^{13}$ also required both thiophosphorylation and alkylation (Figure 1, lanes 1-4). Cell lysates contain abundant free thiols and other nucleophiles, which can react with PNBM, producing close structural variants of $\mathbf{3}$. Therefore, one of the most demanding requirements of $\alpha-3-\operatorname{IgY}$ is the ability to discriminate phosphorothioate $\mathbf{3}$ from thioether $\mathbf{2}$ and other undesired alkylation products. To address this point, whole HeLa cell lysate (WCL) was treated with PNBM and analyzed by western blot. WCL was not recognized by $\alpha-3-\operatorname{IgY}$ irrespective of treatment with PNBM (lanes 5 and 6 , Figure 1). However, if Swe1 thiophosphate $\left(\mathrm{Swe} 1-\mathrm{P}^{\mathrm{S}}\right.$ ) was added to the WCL in the presence of PNBM, Swe1-PS + PNBM was readily detected (Figure 1, lane 7), indicating $\alpha-3-I g Y$ exhibits the desired specificity for $\mathbf{3}$ in the context of whole cell lysate. Similar results were obtained with another Cdk1 substrate, Mob1 (Supporting Information Figure S3). These results demonstrate that alkylation of thiophosphate with PNBM produces an epitope that can be specifically recognized in a complex protein mixture, validating this approach.

Because many antibodies do not recognize their targets with sufficient affinity for immunoprecipitation, ${ }^{14}$ it was important to determine if $\alpha-3-\operatorname{IgY}$ could immunopurify an epitope-tagged substrate from a complex protein mixture. To enable rapid analysis and quantitation of immunoprecipitation experiments, we prepared rhodamine-labeled versions of the kinase substrate Histone $\mathrm{H} 1\left(\mathrm{Rh}-\mathrm{H} 1-\mathrm{P}^{\mathrm{S}}\right.$ and $\left.\mathrm{Rh}-\mathrm{H} 1-\mathrm{P}^{\mathrm{S}}+\mathrm{PNBM}\right)$. $\alpha-3-\mathrm{IgY}$ or preimmune IgY, immobilized on sepharose beads, were incubated with the rhodamine-labeled proteins, washed extensively, and the bound proteins separated by SDS-PAGE and the in-gel fluorescence was imaged. Rh-H1-PS + PNBM bound to $\alpha-3-\operatorname{IgY}$ sepharose beads but not to preimmune IgY; Rh-H1-PS did not bind to either of the antibody conjugated beads, verifying that successful immunoprecipitation requires both the phosphorothioate modification and $\alpha-3-\operatorname{Ig} Y$ (Supporting Information Figure S4).

To examine the dynamic range of the immunoprecipitation, we assayed the efficiency of Rh$\mathrm{H} 1-\mathrm{PS}_{+} \mathrm{PNBM}$ recovery in the presence of varying concentrations of PNBM alkylated cellular proteins. $\alpha-3-\operatorname{Ig} Y$ or preimmune $\operatorname{Ig} Y$ conjugated beads were incubated with increasing concentrations of PNBM alkylated WCL and a constant amount of Rh-H1-P + +PNBM. Recovery of the Rh-H1-PS + PNBM was still possible in the presence of up to $20 \mathrm{mg}$ of WCL (Figure 2, lane 3), although increasing WCL concentrations lowered the yield. The amount of $\mathrm{Rh}-\mathrm{H} 1-\mathrm{P}^{\mathrm{S}}+\mathrm{PNBM}$ present in lane 3, Figure 2, is approximately $800 \mathrm{fmol}(\sim 30 \mathrm{ng})$, a quantity suitable for identification by mass spectrometry, indicating this technique can isolate kinase substrates in cases where the epitope-tagged protein represents approximately $0.005 \%$ of total protein. As the dynamic range of protein abundance in cells is $\sim 10^{6},{ }^{15}$ and since most proteins are substoichiometrically phosphorylated, our results suggest $\alpha-3-\operatorname{IgY}$ can enrich for moderately abundant substrates in WCL or less abundant substrates within partially purified fractions.

We have described a new affinity purification method based on sequential chemical labeling and conjugate specific antibody recognition. Large-scale purification of unknown as kinase substrates from whole cell lysates will likely require production of anti-3 specific monoclonal antibodies, which is currently underway. The method we report here requires a kinase to utilize $\mathrm{ATP} \gamma \mathrm{S}$ as a phosphodonor, and although it is unclear what percentage of the kinome can utilize ATP $\gamma$ S, several kinases have been shown to thiophosphorylate their substrates (see Supporting 
Information Table S5 for a partial list). Combining this purification method with as kinase substrate labeling should provide a general route to the identification of direct kinase substrates. Other biological questions may be approached with tandem chemical/immunological strategies, ${ }^{16}$ which are providing new routes to interrogate the proteome.

\section{Supplementary Material}

Refer to Web version on PubMed Central for supplementary material.

\section{Acknowledgments}

The authors are thankful to Mart Loog for providing Mob1 and Swe1, and Justin Blethrow for Cdk1F80G/cyclinB and assistance with early histone labeling experiments. HeLa cells were generously provided by the NCCC. This work was supported by a grant from the NIH (RO1 EB001987); S.L. was supported by a NIH grant (1 F32 GM63312-01A1). We acknowledge Dustin Maly, Matthew Simon, and Zachary Knight for helpful comments on this manuscript. Mass spectra were provided by the Center for Mass Spectrometry at UC-San Francisco, supported by the NIH Division of Research Resources.

\section{References}

1. Manning G, Whyte DB, Martinez R, Hunter T, Sudarsanam S. Science 2002;298:1912-1934. [PubMed: 12471243]

2. Hubbard MJ, Cohen P. Trends Biochem Sci 1993;18:172-177. [PubMed: 8392229]

3. Beausoleil SA, Jedrychowski M, Schwartz D, Elias JE, Villen J, Li J, Cohn MA, Cantley LC, Gygi SP. Proc Natl Acad Sci USA 2004;101:12130-12135. [PubMed: 15302935]

4. Ficarro SB, McCleland ML, Stukenberg PT, Burke DJ, Ross MM, Shabanowitz J, Hunt DF, White FM. Nat Biotechnol 2002;20:301-305. [PubMed: 11875433]

5. (a) Zhou H, Watts JD, Aebersold R. Nat Biotechnol 2001;19:375-378. [PubMed: 11283598] (b) Oda Y, Nagasu T, Chait BT. Nat Biotechnol 2001;19:379-382. [PubMed: 11283599]

6. (a) Zhang H, Zha X, Tan Y, Hornbeck PV, Mastrangelo AJ, Alessi DR, Polakiewicz RD, Comb MJ. J Biol Chem 2002;277:39379-39387. [PubMed: 12151408] (b) Kane S, Sano H, Liu SC, Asara JM, Lane WS, Garner CC, Lienhard GE. J Biol Chem 2002;277:22115-22118. [PubMed: 11994271]

7. (a) Polson AG, Huang L, Lukac DM, Blethrow JD, Morgan DO, Burlingame AL, Ganem D. J Virol 2001;75:3175-3184. [PubMed: 11238844] (b) Eblen ST, Kumar NV, Shah K, Henderson MJ, Watts CK, Shokat KM, Weber MJ. J Biol Chem 2003;278:14926-14935. [PubMed: 12594221] (c) Habelhah H, Shah K, Huang L, Burlingame AL, Shokat KM, Ronai Z. J Biol Chem 2001;276:18090-18095. [PubMed: 11259409] (d) Shah K, Liu Y, Deirmengian C, Shokat KM. Proc Natl Acad Sci USA 1997;94:3565-3570. [PubMed: 9108016]

8. (a) Mahal LK, Yarema KJ, Bertozzi CR. Science 1997;276:1125-1128. [PubMed: 9173543] (b) Khidekel N, Arndt S, Lamarre-Vincent N, Lippert A, Poulin-Kerstien KG, Ramakrishnan B, Qasba PK, Hsieh-Wilson LC. J Am Chem Soc 2003;125:16162-16163. [PubMed: 14692737]

9. Saxon E, Bertozzi CR. Science 2000;287:2007-2010. [PubMed: 10720325]

10. (a) Gigant B, Charbonnier JB, Eshhar Z, Green BS, Knossow M. J Mol Biol 1998;284:741-750. [PubMed: 9826512] (b) Patten PA, Gray NS, Yang PL, Marks CB, Wedemayer GJ, Boniface JJ, Stevens RC, Schultz PG. Science 1996;271:1086-1091. [PubMed: 8599084]

11. Mouse immune responses were weak (unpublished data).

12. Ubersax JA, Woodbury EL, Quang PN, Paraz M, Blethrow JD, Shah K, Shokat KM, Morgan DO. Nature 2003;425:859-864. [PubMed: 14574415]

13. McMillan JN, Theesfeld CL, Harrison JC, Bardes ES, Lew DJ. Mol Biol Cell 2002;13:3560-3575. [PubMed: 12388757]

14. Gronborg M, Kristiansen TZ, Stensballe A, Andersen JS, Ohara O, Mann M, Jensen ON, Pandey A. Mol Cell Proteomics 2002;1:517-527. [PubMed: 12239280]

15. Gygi SP, Corthals GL, Zhang Y, Rochon Y, Aebersold R. Proc Natl Acad Sci USA 2000;97:93909395. [PubMed: 10920198] 
16. (a) Moore LL, Fulton AM, Harrison ML, Geahlen RL. J Proteome Res 2004;3:1184-1190. [PubMed: 15595727] (b) Dickerson TJ, Yamamoto N, Ruiz DI, Janda KD. J Am Chem Soc 2004;126:1144611447. [PubMed: 15366884] 


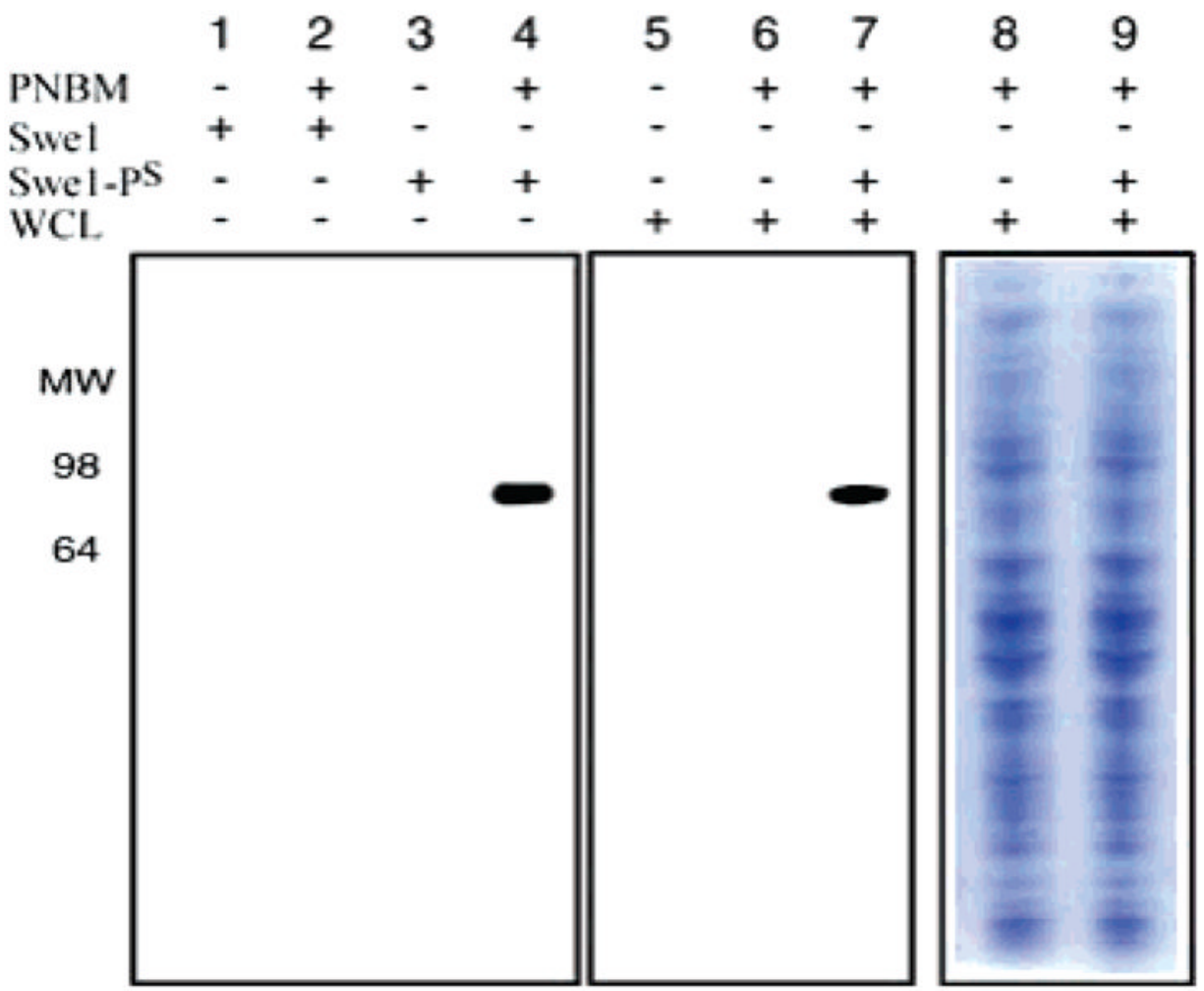

Figure 1.

Recognition determinants for $\alpha$-3- $\operatorname{IgY}$ immunoreactivity measured by western blotting; $25 \mathrm{ng}$ of Swe1 or Swe1-PS was treated with DMSO (lanes 1 and 3) or $2.5 \mathrm{mM}$ PNBM in DMSO (lanes 2 and 4); $15 \mu \mathrm{g}$ of WCL was treated with DMSO (lane 5), $2.5 \mathrm{mM}$ PNBM in DMSO (lane 6), and $25 \mathrm{ng}$ of Swe1-PS plus $2.5 \mathrm{mM}$ PNBM in DMSO (lane 7). Lanes 8 and 9 show coomassie staining of samples identical to 6 and 7, respectively. 


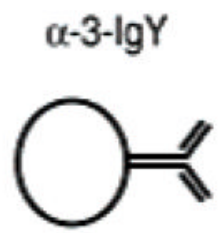

preimmune $\lg Y$

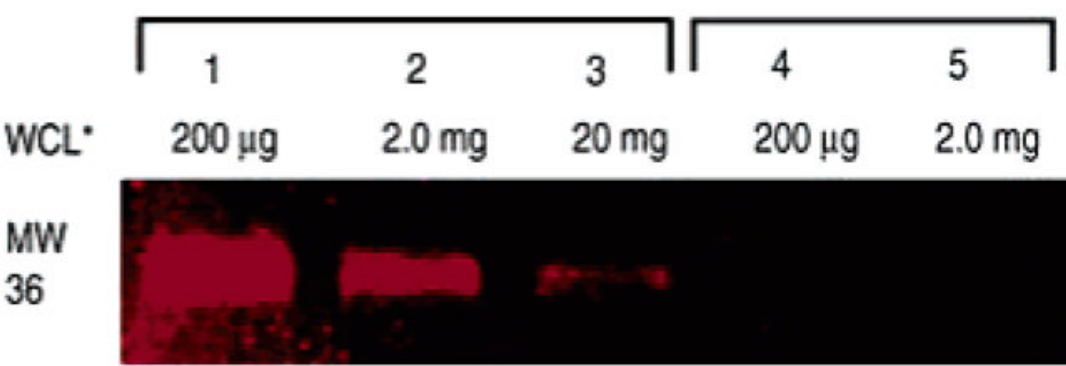

WCL $\quad 200 \mu \mathrm{g} \quad 2.0 \mathrm{mg} \quad 20 \mathrm{mg} \quad 200 \mu \mathrm{gg} \quad 2.0 \mathrm{mg}$

MW

36

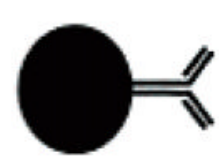

Figure 2.

Immunoprecipitation of Rh-H1-P + PNBM measured by fluorescence of the SDS-PAGE resolved immunoprecipitates. WCL* indicates treatment with PNBM. Lanes 1-3 were treated with $\alpha$-3-IgY sepharose, and lanes 4-5 with preimmune IgY sepharose. 
<smiles>[R]C(O)C(CC)C(C)C</smiles>

as-kinase, A*TP $\gamma \mathbf{S}$
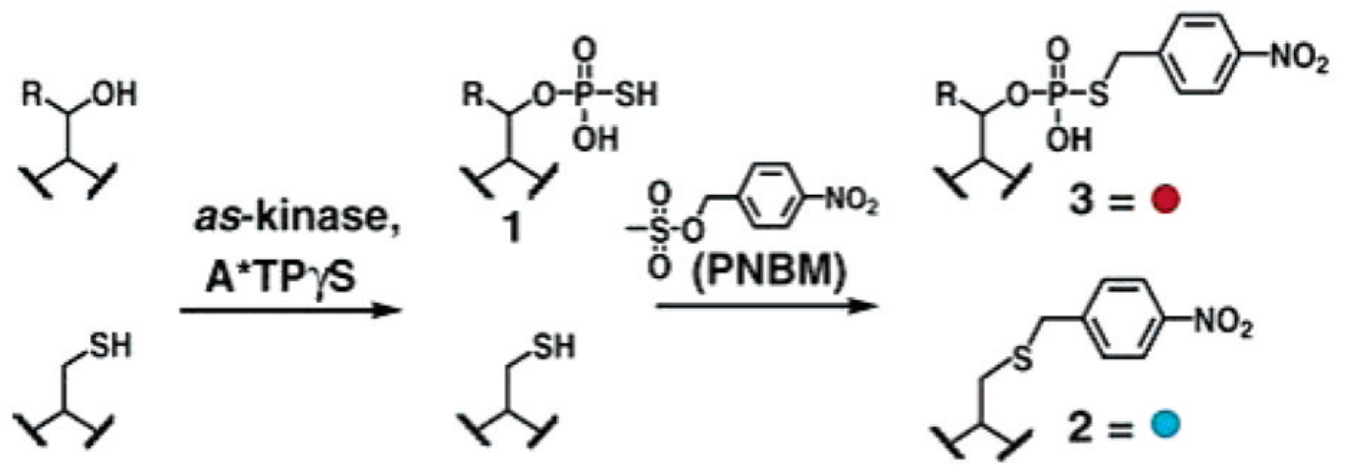

Scheme 1.

Tandem Approach for Creating Bio-orthogonal Affinity Tagged Kinase Substrates (Ser R = $\mathrm{H}$, Thr R = Me) 


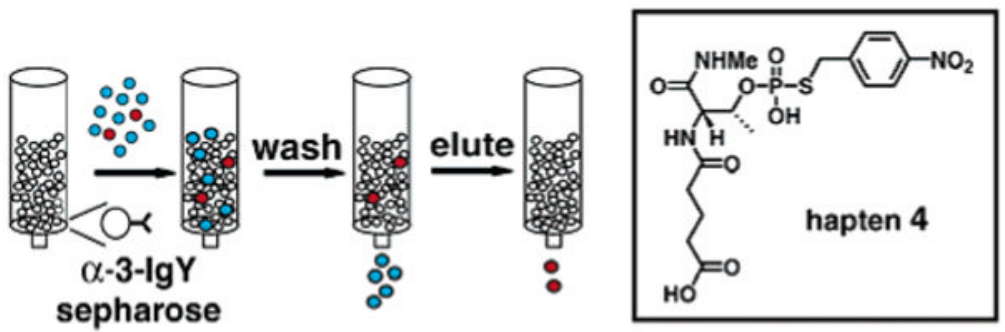

Scheme 2.

Immunoaffinity Purification 